\title{
Chapter 1 \\ The Fourth Wave of Portuguese \\ Emigration: Austerity Policies, European \\ Peripheries and Postcolonial Continuities
}

\author{
Cláudia Pereira and Joana Azevedo
}

\subsection{Introduction}

Few studies have addressed recent emigration from European countries. The refugee crisis and migratory pressure have helped keep academic attention over the last few decades focused on immigration, asylum, reception and integration in Europe. However, these dynamics promoting entries into European countries coexist with other fairly significant dynamics promoting departures from these countries. The sovereign debt crisis coupled with austerity policies that asymmetrically affected Europe's peripheral countries have exacerbated the phenomenon of emigration in various European countries.

These migrant outflows can be observed in the peripheries of Europe - in Ireland (western periphery), Spain, Italy, Greece and Portugal (southern periphery), Poland, Bulgaria, Romania and Latvia (eastern periphery). The migrants that make up these flows have primarily emigrated to Western and Northern European countries, such as Germany and the United Kingdom. More specifically, their migrations have for the most part shifted towards major cities - to London, a "eurocity", in the United Kingdom's case (King et al. 2016). It is important to analyse the impact of inequalities on these outflows, reconciling the perspective of the destination countries with that of the countries of origin and relating this to more widespread processes of socioeconomic globalization.

Our book aims to counter the invisibility of emigration from European countries in the literature by examining the particularities of the Portuguese case. We seek to understand the structural and conjunctural factors that characterise the fourth wave of Portuguese emigration, comparing Portugal's experience of emigration with that of other Southern and Eastern European peripheral countries. We highlight the

C. Pereira $(\bowtie) \cdot$ J. Azevedo

Instituto Universitário de Lisboa (ISCTE-IUL), Centro de Investigação e Estudos de

Sociologia (CIES-IUL), Observatório da Emigração, Lisbon, Portugal

e-mail: claudia.pereira@iscte-iul.pt; joana.azevedo@iscte-iul.pt 
significant volume of outflows in the fourth wave of Portuguese emigration, the direction of these flows, and the profiles of current emigrants. These flows are concentrated within Europe - in both old (France) and new emigration destinations (United Kingdom), ${ }^{1}$ but are also significant outside Europe in historical destinations with post-colonial continuities (Angola and Brazil). Therefore, the fourth wave of Portuguese emigration moves predominantly from southern to northern Europe, but also from the Global North to the Global South. It is argued that the economic recession that followed the 2008 financial crisis played a decisive role in these recent emigration dynamics, together with other factors that are discussed extensively by the authors in this book.

The book compiles the work of authors from different academic backgrounds who have conducted empirical research on Portuguese emigration using a wide variety of extensive and intensive methods. Namely, national and international statistics, large-scale questionnaires, in-depth interviews and ethnography - thus seeking to diversify the range of methodological perspectives and strategies used to understand emigration today. The research presented in this book includes a greater diversity of methodological strategies than did studies of the old waves of emigration. For example, the use of large-scale surveys involving more than 6000 respondents, which enables us to compare Portuguese emigrants living in different countries, as Peixoto et al. do in Chap. 3 (REMIGR 2017). Also, the use of national and international statistics that allow us to compare the Portuguese with other immigrants living in the same country, as Pires and Pereira do in Chaps. 2 and 5, respectively.

Emigration to countries in the three continents of America, Africa and Europe has been a structural feature of Portuguese society since around the nineteenth century - and it has been a large-scale phenomenon both geographically and demographically. In this volume we analyse the similarities and differences between different migratory cycles. For instance, Sardinha and Cordeiro, in Chapters 12 and 13 respectively, discuss the identities of both the old emigrants and their descendants in North America. We also look to the old routes of Portuguese emigration to South America, Africa and Europe that have become attractive again to recent migrants (see Lopes, Queirós, Rosales et al. and Candeias et al. in Chaps. 6, 8, 10 and 11 , respectively).

It is important to provide the key statistical data on Portuguese emigration today in order to better contextualise it within the topics discussed in the book. There are a total of 2.3 million Portuguese emigrants (stock) according to the United Nations (Observatório da Emigração 2018, 31). The calculation of this figure employs the statistical concept of an emigrant, i.e. an individual born in Portugal residing in

\footnotetext{
${ }^{1}$ The United Kingdom has been a destination of Portuguese emigrants since the 1960s, although at that time it received much lower numbers than France or Germany. It was only after 2011 that the UK's population of Portuguese emigrants grew dramatically to levels that exceeded those seen in other countries. The majority of Portuguese emigrants living in the UK before 2011 were in the Northeast and Southeast of England, as well as in the southern islands of Jersey and Guernsey, and were primarily concentrated in London (Almeida 2007; Beswick and Pozo-Gutiérrez 2010).
} 
another country (cf. United Nations 1998). If we add the descendants of emigrants to the total number of emigrants the resultant figure is between five million and 5.5 million (Pires et al. 2014, 79). ${ }^{2}$ The number of Portuguese nationals who moved out to other countries in 2016 was 100,000, as Pires shows in Chap. 2. Between 2008 and 2016 an average of 97,000 Portuguese migrants left the country per year. It is also important to note the number of Portuguese people who have moved back to the country: between 2001 and 2011 more than 233,000 returned to Portugal, according to Peixoto et al. in their chapter on transnationalism and returns. As Lisi et al. point out in Chap. 4, there are 1.375 million Portuguese nationals residing abroad with a potential right to vote in home elections.

Compared to other European countries, Portugal has a small population (roughly ten million), but it is the country in Europe (after Malta) with the second highest emigration rate, and the 12th highest in the world (Observatório da Emigração 2015). About 22\% of Portuguese nationals live outside the country (Observatório da Emigração 2018, 31). The Portuguese are indeed one of the most numerous groups of immigrants resident (stock) in historical countries of Portuguese emigration, such as Brazil and Luxembourg, where they constitute the largest foreign-born population in the country (Observatório da Emigração 2017b, 42-44). They are also one of the largest immigrant groups resident in Switzerland, where they are the third most numerous population, and France, where they are the third largest.

For the first time, this volume brings together authors who have studied previous cycles of Portuguese emigration and now examine today's emigration (such as Rui Pena Pires, João Peixoto and José Carlos Marques) with scholars who started their research during the current cycle. The book thus adopts a comparative perspective on the new wave of Portuguese emigration, examining it from the point of view of those who also studied previous waves, and thus benefiting from longitudinal knowledge of this phenomenon.

Recent research shows us that we are currently seeing the fourth wave of Portuguese emigration. The challenge we set out to meet in this book was to characterise this new cycle, helping to explain its emergence and future prospects. In this chapter we begin, in the first section, by traversing through both past and present cycles of Portuguese emigration, and highlight key issues relating to the ongoing fourth wave. Namely, (i) the economic-financial crisis of 2008 and the resultant austerity policies; (ii) South-North emigration in Europe and Portuguese emigration compared with that from other southern and eastern peripheral European countries; (iii) the reassessment of the "South European model" of migration for the Portuguese case, together with the insights of the model's author, Russell King, in Chap. 14; and (iv) Global North-South emigration. In the second section, we analyse highly

\footnotetext{
${ }^{2}$ Few countries provide data on the descendants of immigrants born in - and with the nationality of - the destination country. Australia, Canada, Denmark, the USA and New Zealand provide some information about the origin of immigrants, although sometimes using very broad categories that refer more to a linguistic-cultural universe (in the case of Portugal the set of Portuguese-speaking countries) than a particular country. Other relevant data for this purpose are consular registers, which include, in addition to Portuguese emigrants, their spouses and descendants (Pires et al. 2017, 79).
} 
skilled and less skilled emigration along the old and new routes of Portuguese emigration by presenting (a) the statistical data on the school education and occupations of emigrants by country, (b) the conclusions on the topic by the book's authors. In the final section we introduce the contents of the book's chapters.

\subsection{The Historical Waves of Portuguese Emigration}

Portugal became a country of emigration in the second half of the nineteenth century. Between its beginning in 1850 and 2000, the history of Portuguese emigration has been characterised by three major waves or cycles (Pires et al. 2011).

The first cycle took place between 1850 and 1930 and followed a postcolonial trend, in which most Portuguese emigrants went to Brazil. This so-called transatlantic cycle, saw a significant volume of Portuguese nationals leaving the country as part of the Great European labour movement to the American continent. As emigrants from Northern Europe left for the Unites States (USA) or Canada, Southern European emigrants followed suit, but an even larger number went to the former South American colonies, which for the Portuguese meant Brazil (cf. Baganha and Marques 2001). The highly unequal distribution of resources motivated the Portuguese to migrate, enticed by the success narratives circulated by previous emigrants, job opportunities and existing migration networks (Peixoto 2000). They were mainly male rural labourers who emigrated permanently due to the difficulty of crossing the Atlantic Ocean to Brazil in this period, among other constraints (Baganha 2003). About two million Portuguese nationals then emigrated to these countries - a very high proportion of the Portuguese population of the time.

The second cycle took place after the end of World War II, between around 1950 and the fall of Portugal's dictatorship in 1974. During this cycle Portugal became one of the main suppliers of migrant labourers in Western Europe (to France and Germany). It was in this cycle that emigration reached its peak between the end of the 1960s and the beginning of 1970s - these record numbers were only reached again in 2011, during the current fourth wave. This second cycle was characterised by the emergence of barriers and restrictive emigration policies enforced by the authoritarian Portuguese regime at the time. These conditions forced the Portuguese to emigrate clandestinely, mostly to neighbouring European countries.

The beginning of this cycle, in the 1950s and 1960s, was probably the period when Portuguese emigration was most global in nature because there was a diversification of destination countries across America, Africa and Europe. There were outflows to Venezuela, Canada, South Africa, Angola, Mozambique and the rest of Europe while emigrants continued to travel to the US and Brazil. At the end of this cycle, flows were concentrated in Europe, and principally in France (Baganha and Marques 2001; Rocha-Trindade 1976). The volume of legal emigration had tripled by the end of this second cycle: from 1956 to 1964, an annual average of 42,000 Portuguese departed and between 1965 and 1973 this average tripled to 126,000 per year (Observatório da Emigração 2018, 17-18). 
During this second wave of Portuguese emigration and the latter part of the first wave, Portugal was under a dictatorial regime. In this second cycle, in a context of economic stagnation and weak modernization, the only way to find better working conditions was to emigrate to nearby Northern European countries like France and Germany. This tendency was part of a broader displacement of the labour force from semi-peripheral Southern Europe to more industrialised Northern Europe, as is taking place in the current fourth cycle. By the end of this cycle, Portuguese emigration had begun to decline following the country's transition to democracy, which created expectations of better living conditions. In addition, the world oil crisis that began in 1973 provoked the closure of borders in many Northern European countries, limiting options for Portuguese emigrants (Peixoto 2000; Pires et al. 2011). This second cycle included more emigrant women than the previous one as well as a higher proportion of Portuguese emigrants in industrial sectors (Baganha 2003). Due to the proximity of other European countries to Portugal, the movements were more temporary. In the absence of reliable statistics, it is estimated that between 1950 and 1974 more than 1.8 million Portuguese nationals emigrated to traditional destinations, principally France and Germany, but also Brazil, the United States, Canada, Angola and Mozambique (Baganha 1994).

The third cycle of Portuguese emigration started after the beginning of democracy in 1974, with the end of political obstacles to emigration, and lasted until around 2000. The start of the free movement of people within the European Union took place during this cycle. Portuguese integration into the EU in 1986 led to an increase in emigration and a surge in the entry of immigrants into Portugal. At that time, researchers' attention was focused on this new movement of immigrants arriving in Portugal; this is why this is the least studied period of Portuguese emigration. Still, emigration continued to be a consistent feature of Portuguese society: between the 1980s and the end of the century, about 20,000 Portuguese migrants left the country per year. In the beginning of the 1990s the outflow reached 45,000 departures per year but dropped again from the mid-1990s, settling to around 20,000 by the end of the decade (Baganha and Marques 2001, 90; Observatório da Emigração 2018, 17-18). Flows were directed primarily to Switzerland and then spread to other European countries, including France and Germany, where networks of emigrants from previous cycles were already consolidated.

The second and third cycles of emigration were not restricted to the Portuguese but common to emigrants from other countries, particularly from the Southern European periphery. The post-war migration of workers from non-industrialised countries included Portuguese but also Spanish, Italian and Greek nationals emigrating to the industrialised countries - such as Germany and France - in search of manual labour. This is theorised in the "Southern European model of migration" by King and analysed by him in greater detail in Chap. 14.

Research on the three initial phases of Portuguese emigration is dominated by historical studies that seek to reconstitute the past and monographic studies that analyse past migrants' identities. References to research conducted on Portuguese emigrants living in about 140 countries may be found in publications that review the 
field (Rocha Trindade 1984; Baganha and Góis 1999; Peixoto 2012; Candeias, Ferreira and Peixoto 2014; Candeias et al. 2014).

In the wave of studies on Portuguese emigration that has emerged over the past few years, some authors have attended to the issue of identity among Portuguese emigrants and their descendants. They have studied the religious festivities celebrated by Portuguese emigrants from the Azores living in North America, and the newspapers, TV and radio produced by Portuguese emigrants and their descendants, among other examples (Leal 2017; Ferreira 2016). In Chaps. 8 and 10 of this book, Queirós and Rosales et al. draw attention to the identities of - and the meanings of social and professional (de)mobility among - the Portuguese in Spain, France and Brazil. In Chap. 12, Sardinha looks at the descendants of emigrants who tried to live permanently in the idealised homeland of the parents, Portugal, and left disillusioned, continuing to experience transformations in their identities. Cordeiro deepens our understanding of the (dis)identification of emigrants with the category of "emigrant" and the social meaning attached to it by citizens in Portugal.

\subsection{The Fourth Wave of Portuguese Emigration}

Portuguese emigration is now in its fourth cycle. We argue that the fourth cycle of Portuguese emigration started around 2001 with the stagnation of the European economy and consequent increased unemployment - a period that coincides with the end of the circulation of the national currency, the escudo, and the beginning of the Eurozone's common currency, the euro. The number of Portuguese nationals leaving the country increased exponentially in 2011, the second phase of this cycle, at the time of the country's sovereign debt crisis and ensuing economic containment policies, which accelerated the growth of the unemployment rate. For the first time, the number of Portuguese nationals leaving the country reached the same level as during the previous peak of Portuguese emigration in the 1960s: an average of 115,000 Portuguese nationals emigrated per year between 2013 and 2015.

During the first phase of this wave, the number of Portuguese nationals moving to other countries began to increase progressively, rising from 45,000 in 2001 up to 90,000 in 2007 - double the number emigrating at the start of the decade. ${ }^{3}$ During

\footnotetext{
${ }^{3}$ The data collected by the Portuguese Emigration Observatory (Observatório da Emigração) is obtained from the institutions responsible for immigration statistics in destination countries. More precisely, it is based on the information about Portuguese entries that the annual estimates of total Portuguese emigration are drawn up by Emigration Observatory, which are generally higher than the estimates produced by the Instituto Nacional de Estatística (Portuguese National Statistics Institute) (INE). Figures on permanent Portuguese emigration published by the INE and Eurostat whose numbers are based on those of the INE - are underestimates. This becomes clear when they are compared to those calculated by the Emigration Observatory based on records of Portuguese arrivals in destination countries. The main source of information used by the INE to estimate international migrations to and from Portugal is the "Inquérito ao Trabalho" (Labour Force Survey), conducted by sampling. In the case of immigration, the results thus obtained are subsequently
} 
this period, emigration continued to be predominantly European, flowing to the traditional destinations of Germany, France and Switzerland and one new country, Spain. In fact, Spain also became the destination to which the Portuguese emigrated most often in the first decade of the twenty-first century. Three thousand Portuguese nationals moved to Spain in 2001, and by 2007 that number had risen to 27,000, revealing enormous growth in 6 years (see Fig. 2.8 in Pires' chapter). The majority of Portuguese nationals who emigrated worked in civil construction and services (Pinho and Pires 2013). With the financial crisis of 2008, which greatly affected the construction sector, many Portuguese emigrants lost their jobs and either returned to Portugal or re-emigrated to England or France (see Queirós' chapter). Emigration to Spain fell over the following years, although it continued to be one of the five main destination countries for Portuguese emigrants.

Emigration decreased from 2008 to 2010 - as it did globally among OECD countries affected by the financial crisis - although the figure remained at a high plateau of over 70,000 Portuguese emigrants per year. The second phase of this cycle began in 2011, when a large increase in Portuguese emigration combined with low levels of immigrant inflows to produce negative net migration. The dynamics of Portuguese emigration from 2011 onwards are analysed in more detail in the following sub-section.

In this book we have challenged various authors from different disciplinary areas - all of whom are conducting research in this field - to reflect on Portuguese emigration today. The book's fourteen chapters reveal analytical themes that we feel must be highlighted in order to understand recent Portuguese emigration:

(i) the impact of the 2008 economic-financial crisis and austerity policies;

(ii) south-north emigration in Europe;

(iii) north-south emigration outside Europe and post-colonial continuities;

(iv) the importance of reassessing the existing Southern European migration model;

(v) highly skilled and less skilled migration along the new and old routes of Portuguese emigration;

(vi) emigrants' and their descendants' identities.

The fourth and current wave of Portuguese emigration will be characterised below by its distinguishing features.

corrected after comparison with the administrative records of entries held by the Serviço de Estrangeiros e Fronteiras (Immigration and Borders Service). For emigration, not only is there no national administrative register that allows a similar adjustment, as mentioned earlier, but - as the inquiry procedure is indirect - since those who have left cannot, by definition, be questioned. The result of this asymmetry in statistics on exits and entries has resulted in an underestimation published by Eurostat that is then used to calculate net migration. Hence it is probable that net migration is lower than recorded in both national and European statistics (Observatório da Emigração 2017a).

The numbers of Portuguese nationals emigration per year, as calculated by the INE and Emigration Observatory, are presented in table E.2, here: http://observatorioemigracao.pt/ np4EN/1315/ 
During the 10 years between 2004 and 2013 Portugal became one of the EU and EFTA countries with the highest negative net migration. In absolute terms, only Poland, Greece and Spain had higher negative values for net migration, and if we discount returnee flows of emigrants, Poland and Romania are the only countries to lag behind Portugal (Observatório da Emigração 2015, 12-13).

Based on destination countries' permanent inflow data, between 2008 and 2012 an annual average of 80,000 Portuguese nationals emigrated, and in 2013 this number reached a peak of approximately 120,000 (both estimates).

Two facts distinguish the demographic impact of recent Portuguese emigration in both the country of origin and the destination country. First, as already mentioned, compared to other European countries, Portugal has a small population (roughly ten million), but it is the country in Europe with the second highest emigration rate (after Malta), and the 12th highest in the world (Observatório da Emigração 2015). Second, following the financial crisis of 2008 the Portuguese have become one of the most numerous nationalities entering European countries.

According to the most recent data available, in 2014 Portuguese nationals constituted the majority of new immigrants in France. In 2016, the Portuguese made up the second-largest national group entering Luxembourg, the fourth-largest in Switzerland and the seventh-largest in the United Kingdom. Outside Europe, they were also the tenth-largest national group in Brazil (Observatório da Emigração 2015, 38).

Among the main factors that help explain this high number of Portuguese nationals leaving since 2011 we should highlight three factors. First, Portuguese emigration has not ceased since the 1960 s, even when counterbalanced by immigration in the 1980s and 1990s. Second, the sovereign debt crisis and austerity measures implemented after 2011 - which followed the financial crisis and affected the countries of the peripheral south of Europe, including Portugal - swept heightened unemployment and consequent drastic reductions in job offers into the country. Third, there was a second, more structural and permanent, crisis - that of unemployment among young qualified Portuguese people, which led many to seek employment outside the country (King 2015).

\subsubsection{The Economic-Financial Crisis of 2008 and Austerity Policies}

The concentration of Portuguese emigration in Europe increased following Portugal's integration into the European Union in 1986, and its citizens' subsequent entitlement to free movement within EU countries. The research conducted by the book's authors shows that two changes later occurred in Portugal - as they did in all the peripheral countries of Europe - that played a decisive role in increasing the outflows: the entry into the Eurozone (2000); and the recession caused by the sovereign debt crisis and austerity policies implemented in the country, which had the greatest impact from 2011 onwards. 
When the majority of European countries adopted the common currency, the Euro, in 2000, the competitiveness of Southern European countries declined and their employment rates fell (cf. Teixeira et al. 2014; Mamede 2016; Gibson et al. 2014; Reichlin 2014). The availability of Community funds - created to mitigate this problem - also fell, because the European Union now had more or less the same budget divided by more countries. Portuguese exports became more expensive due to the high value of the euro (Mamede 2016) and the European Union ceased to be a space of economic convergence. Industry became less competitive, further exacerbating unemployment (Teixeira et al. 2014). With a rise in the unemployment rate and constraints on the labour market, a significant part of the population of the Southern European countries sought employment in the countries of Western and Northern Europe. However, the outflows of emigrants declined with the financial crisis of 2008, whose global impact led to a reduction of employment across European countries (Herm and Poulain 2012; OECD 2011, 30).

Nevertheless when economic recovery was underway in Western and Northern European countries such as Germany and the United Kingdom, some 3 years later the countries of the South started to experience a sovereign debt crisis due to the use of external loans. This led to austerity policies that resulted in turn in the curtailment of growth ${ }^{4}$ - in other words, in decreased employment and consequently increased emigration to countries with employment offers. The recession and austerity measures that affected Portugal further entrenched uncertainty about the future, prompting many to seek to leave the country. At an international level, the link between emigration and recession concerned various authors (Bygnes 2015; Bartolini et al. 2016; Triandafyllidou and Gropas 2014; Lafleur and Stanek 2016; King et al. 2016; Parutis 2014; Triandafyllidou and Isaakyan 2016). The first findings about the relationship between the financial crisis and the increase in Portuguese emigration began to emerge in 2014 and research has continued ever since (Gomes et al. 2015; Peixoto et al. 2016; Oliveira et al. 2016; Canavarro et al. 2014; Pereira 2015; Pires et al. 2015; Ganga et al. 2016; Justino 2016; Santana-Pereira and Horta 2017; Marques and Góis 2013; Leite et al. 2017; Farcas and Gonçalves 2017).

There was one push factor that was particularly significant in prompting such a high number of people to leave the country during the period of economic austerity: the accentuated growth of the unemployment rate among young people. The unemployment rate among this group rose by 21 percentage points between $2008(16.7 \%)$

\footnotetext{
${ }^{4}$ More precisely, due to the economic and financial crisis in international markets since 2008 and the inability of the Portuguese government to incur debt at reduced rates, the Portuguese authorities requested financial assistance from the EU in 2011. An Economic Adjustment Programme was negotiated with a team of officials from the European Commission, the European Central Bank and the International Monetary Fund, together known as the Troika. Financial rescue plans were negotiated for seven countries besides Portugal, namely Greece, Cyprus, Ireland, Hungary, Latvia, Romania and Spain (cf. https://ec.europa.eu/info/business-economy-euro/economic-and-fiscalpolicy-coordination/eu-financial-assistance/which-eu-countries-have-received-assistance_en). This financial assistance to aid economic growth and restore investor confidence was provided between 2011 and mid-2014.
} 
and 2013 (38.1\%) (PORDATA-INE 2017). By comparison, unemployment among adults aged 25-64 was lower in 2008 (6.9\%) and by 2013 had increased by only 8 percentage points. At the same time, the total unemployment rate grew by 9 percentage points between 2008 and 2013, from 7.6\% to 16.2\% (PORDATA-INE 2017). This resulted in a shrinking labour market with far fewer job offers, pushing many working-age Portuguese nationals to emigrate in search of employment opportunities.

In qualitative terms, working conditions have become more precarious due to the austerity imposed by EU policies to combat the economic recession. More specifically, greater flexibility has been granted for indemnity where jobs have been eliminated; salaries have been cut and working hours increased; vacation and 13th-month subsidies have been reduced; and career progression has frozen (cf. Pedroso 2014). These measures were implemented to combat the deficit and reduce external dependence. Yet according to a study on the impact of austerity on the economy, the welfare state and the performance of the Portuguese state in general, these measures also instigated "more poverty, more unemployed with less benefits, [and] substantial cuts in old age pensions and the national health service: austerity and recession bring growing social problems while reducing public responses to these problems" (cf. Pedroso 2014, 1).

One of the consequences of these poorer working conditions is visible in the construction sector, which has suffered a huge decline. Because governmentsupported projects and housing construction practically came to a halt, a large number of workers were forced into unemployment and left the country. Indeed, among Portuguese people with the lowest school qualifications, those working in the civil construction sector were among those most affected by austerity, which led many of them to emigrate from 2011 onwards to Angola, Spain, the UK and France (Chap. 11 by Candeias et al. and Chap. 8 by Queirós).

Additionally, Portuguese society is one of the most unequal in the EU in terms of wealth distribution. The deceleration of GDP growth and increasing precariousness of working conditions have further exacerbated this situation (Carmo et al. 2018). The severity of unemployment in Portugal is "transforming into a structural variable that affects other economic and social dimensions, such as income inequality" (Carmo and Cantante 2015, 49).

Increased inequality in Portugal has contributed to processes of deprivation, which have not only led to the emigration of the less skilled, but also to the outflow of highly skilled, middle-class Portuguese nationals. In Portugal, as in other peripheral European countries, the middle-class is at permanent risk of sudden impoverishment (Estanque 2016). This macro-dimension factor lay behind the decision of many highly skilled Portuguese professionals in different sectors to seek employment in other countries.

In Portugal, austerity policies were accompanied by political rhetoric encouraging emigration on the part of the governments that implemented them. Thus, in 2011, politicians from the conservative coalition (Portugal à Frente) ${ }^{5}$ within the

${ }^{5}$ Portugal à Frente was a right-wing electoral alliance formed by the Social Democratic Party (PPD/PSD) and CDS-PP. 
Portuguese government encouraged young people to "leave their comfort zone" and go abroad in search of new opportunities: first, by the Secretary of State for Sports and Youth, Alexandre Mestre, who declared that "if we are unemployed, we have to leave the comfort zone, and go beyond our frontiers", and then by Miguel Relvas, Deputy Minister and Minister for Parliamentary Affairs, who affirmed that "[for] those who believe that they can find [opportunities] outside their country, in a relatively short timeframe, with the prospect of return if necessary, but who can strengthen their education, can confront other cultural realities, [this] is extraordinarily positive" (Jornal de Negócios 2013). These discourses encouraging departure were reinforced by the Prime Minister at the time, Pedro Passos Coelho. In the face of growing unemployment that hit young people extremely hard, particularly in the education sector, Passos Coelho suggested that unemployed high school teachers move to Portuguese-speaking countries such as Brazil or Angola, grasping the opportunities of "the Portuguese language market". Opposition political parties strongly condemned these declarations and mobilised around the topic of emigration in both their discourses and political action.

In this context of uncertainty - which comprised limited opportunities for social mobility, unstable labour market integration, a strong contraction of the welfare state, and the absence of professional opportunities - emigration emerged as a strategy adopted to overcome this socioeconomically restrictive scenario.

\subsubsection{South-North Emigration in Europe}

The majority of recent empirical research has focused on Portuguese nationals who have emigrated within Europe. The statistics suggest that in 2010 - and up until 2016 - more than two thirds of Portuguese emigrants resided within European countries. In terms of flows, more than $85 \%$ of Portuguese nationals who left the country during these years were migrating within Europe.

The data reveals a movement of Portuguese emigrants from Southern Europe to the North of the continent. According to King, there is a historical sequence of migration common to Spain, Greece, Italy and Portugal, which the author theorised as the "Southern European model of migration". This sequence started in the aftermath of the Second World War (King 2000), and is currently in its fourth stage, the “New emigration' of young, well-educated people seeking employment and new lifestyle experiences in North Europe, since the nineties, accelerating after 2008 (King 2015, 139)". In King's words, the three previous stages of Southern European migration can be summarised as movements of emigration (1st phase), return (2nd phase) and immigration (3rd phase). In further detail,

Emigration, mainly low-skilled labour migration, to North-West Europe and other parts of the world (...), 1945 to the early-mid seventies. Return migration, seventies and eighties: but some forms of return are still ongoing such as 'retirement return' and the 'pseudoreturn' of the second generation, born abroad of migrant parentage. Immigration from a 
wide variety of countries worldwide, (...), eighties to today, but slackening off since 2008 . (King 2015, 139)

In the current phase of "new emigration", King suggests that two crises have coincided, one conjunctural and another structural, both economic. The emigration of skilled young people from Southern Europe was the result of the 2008 financial crisis, but it also reflected a deeper structural crisis present for around two decades that of graduate unemployment (King 2015, 158).

This model fits within a "centre-periphery framework", according to King in Chap. 14. The geographic peripherality of these Southern European countries combines with their economic "peripherality" to produce fragile economies, as revealed in the aftermath of the 2008 financial crisis, when their structural dependency on the economies of the "centre" - i.e. Northern and Western European countries (King 2015) - became clear. In fact, during this period the UK, Germany, France and Switzerland were the countries that most attracted the emigrants of Southern European countries (Domínguez-Mujica and Gracía 2017, 42). The dependency of these countries is also explained by the push factor mentioned earlier: the four Southern European countries have the highest youth unemployment rates in the European Union (EU) (ranging from 31\% to 48\% in 2015) (Bartolini et al. 2016, 3).

Some authors have already drawn attention to parallel emigration from other peripheral European countries in the same period. Starting with the southern periphery, the recent emigration of Italians has been researched from the perspective of their insertion in the labour market of their destination country, such as Germany (Castellani 2018). The recent emigration of Spanish nationals to the UK, Germany, Norway and other core countries has been studied with a focus on the highly skilled, among other themes (Christiane and Oliver 2017; Cortes et al. 2015; Bygnes 2015; Faraco Blanco 2014; González-Ferrer 2013; Herrera 2014; Ros 2013). From the Western periphery, the recent emigration of Irish nationals - mainly to the UK - has been profiled and related to previous cycles of Irish emigration (Glynn et al. 2013). Other researchers have developed comparative analyses of emigrants from Southern and Eastern European peripheral countries to Western and Northern European countries following the crisis of 2008, which has opened up broader perspectives on migratory dynamics within the European continent (Bygnes and Erdal 2017; Bartolini et al. 2016; Lafleur and Stanek 2016; King et al. 2016; Parutis 2014; Raffini 2014; Triandafyllidou and Gropas 2014; Triandafyllidou and Isaakyan 2016).

Although there are similarities, there are also significant differences between the Southern European countries with respect to migration which will be further analysed in the following sub-section. As Jean-Michel Lafleur and Mikolaj Stanek observe in their book, South-North Migration of EU Citizens in Times of Crisis:

transformations between pre and post crisis in migration patterns are not uniformly visible in the case of Southern European countries. The case of Portugal differs significantly from others due to the larger volume of migration flow compared to its overall population. [...] Unlike other Southern EU Member States, migration from Portugal has never ceased. (Lafleur and Stanek 2016, 217) 
In Chap. 5, Pereira compares the emigration of Portuguese nurses with that of Spanish, Italian and Romanian nurses occurring at the same time and heading to the same core countries in Europe. By combining data on both emigration and immigration, Pires compares the overall migration profile of Portugal with that of other European countries in Chap. 2. He concludes that Portugal is placed not in a similar position to that of Southern European countries but rather to that of Eastern European countries, whose populations mainly move out and into which few immigrants move in. This contrasts with the other Southern European countries, where people leave to other countries but a considerable number of immigrants also enter.

\subsubsection{Reassessment of the "South European Model" of Migration for the Portuguese Case}

The South European model of migration was developed at a time, around 1990, when these countries were all predominantly sending countries - countries of emigration - but were also starting to become receiving countries - countries of immigration (King 2000). The model enabled researchers to identify that all of these countries had experienced similar migration processes since the aftermath of the Second World War, as described above.

With the financial crisis of 2008 and the ensuing austerity policies, there was a visible increase in the number of those leaving Southern European countries while at the same time immigrants and refugees continued to arrive, although these latter flows were not observed in the Portuguese case. In Portugal there was an exponential increase in Portuguese nationals as well as immigrants leaving the country, but the number of entries of migrants into the country fell (cf. Pires and Espírito-Santo 2016). The post- financial crisis immigration movements of 2008 differentiated Portugal - which had a low volume and flow of immigration - from the trend observed in Spain, Italy and Greece, where migrants continued to arrive in larger numbers.

For this reason, in the comparison of the gross emigration rate with that of the immigration rate in each country, Spain, Italy and Greece fall under the migratory profile of countries with more immigration than emigration, while Portugal is among the countries with more people leaving than entering. In terms of the balance between emigration and immigration, Spain, Italy and Greece have profiles similar to those of Belgium, France, Holland and Slovenia, where immigration surpasses emigration. By contrast Portugal, with a high gross emigration rate (23\%) and low gross immigration rate $(8 \%),{ }^{6}$ has a migratory profile more similar to that of Lithuania, Romania, Bulgaria and Poland (see Fig. 2.10 in Chap. 2, by Pires).

\footnotetext{
${ }^{6}$ Gross emigration rate: stock of permanent emigrants in any given year as a percentage or a ratio of the resident population of the country of origin in this same year. Gross immigration rate: stock of permanent immigrants in any given year as a percentage or as a ratio of the resident population of the destination country in this same year.
} 
The particularity of Portugal's position within global migration patterns has also been studied in the context of the Lusophone migration system, in which Portugal has migration networks with countries in the Global South where the Portuguese language is spoken, such as Brazil and Angola (Góis and Marques 2009). Recent re-emigration from these two countries is analysed in Chaps. 10 and 11. This data and the results of research presented in this book suggest that it is important to reassess the application of the South European model of migration to Portugal.

\subsubsection{North-Global South Emigration}

North-South emigration is another of the features that distinguishes Portugal from other Southern European countries. Today's emigration to Angola, Mozambique and Brazil continues to receive little attention from researchers (Akesson 2016; Santos 2013; Peixoto et al. 2016). In Chap. 11, Candeias et al. show that within the growth process of Portuguese emigration that led the country back to negative net migration in 2010, outflows to the Global South, although not dominant, played a relevant role. These flows - clearly stimulated by the 2005-2015 economic recession as well as by the severe austerity measures applied between 2011 and 2014 were mainly to Portuguese-speaking countries, especially Angola, which was the main destination (despite the fall in migration flows observed after 2013-2014).

The authors demonstrate that, from a broader theoretical perspective, recent migration from Portugal (a former metropolis) to Angola (a former colony) is a strong example of North-South migration that challenges some classical premises espoused by both migration theories and post-colonial studies. The profile of emigration that emerges seems to support the theory that the emergence and development of North-South migratory movements relate to the economic expansion and increasing integration of parts of the Global South into global economic, political and even technological networks. At the same time, the authors find little evidence to back up the theory, suggesting that recent Portuguese emigration to Angola is largely a form of ancestral return, that is, a form of migration that mostly involves people who have some kind of specific ex-ante knowledge of and/or affective bond with Africa connected to previous migratory processes involving family or friends who settled there during the colonial period.

Rosales and Machado (Chap. 10) look into the transatlantic movements between Portugal and Brazil, arguing that despite the differences between new and former contingents, history, the existence of colonial and post-colonial ties, and the shared language seem to play an important role for emigrants. The postcolonial representations of the "new" emigrants reproduce "old" colonial reifications of a stratified relationship, expressed nowadays in the derogation of some Brazilian institutions and the simultaneous exoticization of the "Brazilian easy way of life". 


\subsection{Highly-Skilled and Less Skilled Migration Along New and Old Routes of Portuguese Emigration}

In both academic research on recent Portuguese emigration and in the media, increasing attention has been given to highly-skilled people leaving the country even though many Portuguese people with only elementary or secondary education continue to emigrate. In this section we summarise the available statistics, we compare the level of education of Portuguese nationals with that of other immigrants within the same country and also with Portuguese nationals in other countries.

Skilled Portuguese workers' main reasons for emigration are varied and are principally (i) to get a job, (ii) to work in their area of education, (iii) to study, or (iv) to progress in their professional career. These drivers of migration have been revealed by recent research projects on Portuguese emigration in times of crisis (Ganga et al. 2016; Oliveira et al. 2016; Peixoto et al. 2016; Pereira et al. 2015; Lopes 2014; Pereira 2015).

Between 2001 and 2011 there was considerable growth (70\%) in the proportion of Portuguese-born migrants with high educational attainment, i.e. a shift from $7 \%$ to $11 \%$. Still, Portuguese migrants with a basic level of education make up the largest group (62\%). More than a quarter $(27 \%)$ had a medium level of education (Observatório da Emigração 2015, 96-97). The most recent statistics about qualifications among Portuguese emigrants are those from the 2011 census, which were harmonised for analysis by the OECD through the DIOC database. However, the latest censuses refer to Portuguese emigrants who are already residents in their destination countries and do not include those who have recently arrived there.

The pattern of Portuguese skilled migrants is very heterogeneous and varies according to their destination country, as Pires shows in Chap. 2. In 2010/2011 the proportion of Portuguese-born migrants with high educational attainment was $7 \%$ in France, $6 \%$ in Switzerland and $4 \%$ in Luxembourg, compared to $38 \%$ of those living in the United Kingdom. The two main current destination countries, the UK and France (in terms of permanent inflows, 2016), thus have very different profiles when it comes to the qualifications of Portuguese nationals residing there: $38 \%$ and $7 \%$ respectively have higher education qualifications. In France the proportion of Portuguese immigrants with only basic education $(70 \%)$ is much higher than the proportion of those with higher education, while in the UK the proportions are similar, with 35\% having only basic education (Cândido 2018, 11).

We may compare Portuguese emigrants with the other immigrants living in the same destination country in order to achieve a broader, more comparative, analysis. In a study about the USA, Espírito-Santo and Pires show that, like immigrants from Latin American countries, Portuguese emigrants tend to have low levels of formal education - in contrast to the generally high qualifications of European and Asiatic immigrants (Espírito-Santo and Pires 2014, 49, 61). This is understandable when we take into consideration the low formal education levels of the Portuguese in the 1970s, the time of the largest outflow to the USA (idem, 49). But so far studies of 
Portuguese emigration have lacked comparisons with other immigrants within the same country, and for that reason few illustrative cases are presented in this book.

On another scale of comparison, of all destination countries for Portuguese emigrants, in 2001 the UK had the largest proportion of qualified Portuguese nationals (19\%) followed by the USA (11\%) (Espírito-Santo and Pires 2014, 69). In her chapter in this book, Delicado shows that the USA and UK have been the top destinations for Portuguese scientists. In 2011 the countries with the largest proportion of highly qualified Portuguese immigrants were the ones in which the Portuguese arrived recently, i.e. 1 year ago or less, such as UK and Norway (Observatório da Emigração 2015).

Moreover, the largest increase in Portuguese emigration happened from 2010 onwards and thus, unfortunately, there is still no census data that reflects this movement. The only data available on Portuguese emigrants who have recently entered into European countries that record their school qualifications are those from France, relating to 2012. The Portuguese were the lowest qualified among all recently-arrived immigrants, together with the Turkish: in both cases only $14 \%$ had higher education (Brutel 2014).

Only in the next censuses will we be able to access more accurate information about the qualifications of Portuguese emigrants who left the country from 2011 onwards. As the UK is the main destination and at the same time the country with the highest number of qualified Portuguese emigrants, we estimate that the number of Portuguese emigrants with higher education will have increased in this country. Once new census data is released we will also be able to assess the effects of Brexit, and in particular the impact of restrictive UK immigration policies on the entry of Portuguese emigrants into the country.

When it comes to the relation between qualifications and occupations, most Portuguese emigrants have predominantly less skilled jobs. This is related to the fact, mentioned earlier, that the majority have either only basic or medium levels of education. In 2010/2011, only about a fifth (19\%) of employed Portuguese-born migrants had highly- or very highly-skilled occupations (managers, professionals and technicians). Still, as happens with the variable of qualifications, this highlyskilled occupational structure ${ }^{7}$ is very different across destination countries, ranging from $10 \%$ in Luxembourg and $27 \%$ in United Kingdom to more than $40 \%$ in Denmark, Sweden and Ireland (Observatório da Emigração 2015, 94-96).

Two of the three chapters on skilled emigration in this book reveal that the United Kingdom is the top destination for a particular professional group of Portuguese emigrants: for Portuguese nurses, according to official statistics - Chap. 5, by Pereira - and, together with the United States, for Portuguese scientists, according to a survey - Chap. 7, by Delicado. The "new" emigration of highly skilled Portuguese emigrants along an "old" route - to France - is analysed in Chap. 6 by Lopes.

${ }^{7}$ ISCO 1/2/3 (OECD levels of classification). 


\subsection{What This Book Is about}

The book is divided into five parts, with 14 chapters organised by themes related to recent Portuguese emigration:

(a) New patterns of Portuguese emigration: A broad perspective;

(b) The labour market and Portuguese emigration: Highly skilled and less skilled migrants;

(c) Portuguese emigrants: Postcolonial continuities;

(d) Portuguese emigrants: Identities;

(e) Final reflections.

The first section presents a broad perspective on the new profiles of Portuguese emigration. These chapters relate the austerity measures taken following the financial crisis to increased levels of Portuguese emigration, and offer insights on the position of Portugal as a sending country in one of Europe's peripheries. They also address issues related to the country of origin, such as return migration and emigrants' rights to political representation in Portugal.

In Chap. 2, "Portuguese Emigration Today", Pires theorises about recent Portuguese emigration and immigration. He also discusses its evolution since 1974, the year that the Portuguese government stopped being a dictatorship and became a democracy, paving the way for new migratory dynamics. He bases his analysis on a statistical data set drawn both from origin and destination countries as well as international organisations. His first main finding is that Portuguese emigration became mainly European. Portugal's entry into the Eurozone and the financial recession towards the end of the last decade led to a reduction in job creation, and emigration consequently accelerated as way of filling this gap. Pires concludes that Portugal's position is similar to that of East European countries, where the population mainly leaves and few foreigners enter, resulting in a strong negative net migration rate the inverse of what happens in most West and North European countries. He finishes by discussing migration and demography, and by proposing public policies concerning emigration and immigration.

Chap. 3, "New emigration and Portuguese society: transnationalism and return", by Peixoto et al., presents findings of a research project on Portuguese emigration carried out from 2013-2015 called "Back to the future: new emigration and its relationship with Portuguese society". It analyses Portuguese emigrants who moved to countries in Europe (UK, France and Luxembourg), South America (Brazil), and Africa (Angola and Mozambique). Based on a large-scale questionnaire survey with more than 6000 respondents the authors characterise recent Portuguese emigrations. Moreover, they analyse the official statistics from the Portuguese Census in 2001 and 2011 on returning emigrants. These extensive methods were complemented by 45 semi-structured interviews.

This broad sample taken from six countries provided a comparative perspective on the "new" routes of Portuguese emigration. More precisely, on the kind of 
transnational relationship the new emigrants have with Portugal based on the links they maintain with their home country and new patterns of return.

The first main conclusion is that the new emigrants engage in two main transnational practices: visits to the country of origin and remittances. While it is possible to identify changes in the mobility patterns of some emigrants and an eventual decrease in their transnational financial practices with Portugal, other emigrants keep the home country as a reference point of their social lives and hold on to returning as a goal.

The second main conclusion concerns the number and diversity of returns. Between 2001 and 2011 more than 233,000 Portuguese emigrants returned to Portugal. One key profile is embodied by the Portuguese emigrants who returned from traditional destinations in the 1960s and 1970s, such as France, who are mostly from older age groups, have low levels of formal education, and are retired. These characteristics constitute the most representative returnee profile, accounting for $48 \%$ of the total over the decade. The second main profile is embodied by the Portuguese emigrants coming from new emigration destinations (39\%), such as the UK and Spain, who are mainly young adults with heterogeneous skills. Compared to emigrants matching the previous profile they have more formal education, are younger, are more often men and more often unemployed. The third key profile is of returnees (13\%) from countries both within Europe (e.g. Italy) and outside Europe, the so-called "Lusophone" countries (e.g. Angola and Mozambique). They are mostly male, with an average age between that of the previous two profiles, and have the highest level of education.

In Chap. 4, "Portuguese Emigrants' Political Representation: The Challenges of the External Vote", Lisi et al. analyse the e representation of Portuguese emigrants in home-country elections during the democratic period (1976-2017). Over the last few decades, emigrants across the globe have gained expanded voting rights in home-country elections. The authors analyse the evolution of external voting both during the "old" waves of emigration (external voting was implemented in 1976, at the beginning of the third wave of Portuguese migrating abroad) and during the "new", recent wave of emigration. Furthermore, they evaluate the performance of the electoral system and the current limitations of Portuguese emigrants' political representation.

Lisi et al. suggest that a combination of political and socio-economic factors explains the implementation of external voting in the Portuguese case. The interests of political parties and the low level of civil society engagement lie behind the failure of electoral reforms and of attempts to overcome the shortcomings of external voting. The new wave of Portuguese emigration has reopened the debate about emigrants' political representation, leading recently to the expansion of eligibility and reassessment of voting methods.

The second section of the book takes a deeper look at the labour market insertion of highly skilled and less skilled Portuguese emigrants.

In Chap. 5, "A New Skilled Emigration Dynamic. Portuguese Nurses and Recruitment in the Southern European Periphery", Pereira presents the role of recruitment agencies in the profession apparently most affected by recent skilled 
emigration: nursing. The author combines intensive and extensive methodologies. She collected official statistics from the six main destination countries and analysed the evolution of outflows of Portuguese nurses - most of whom were women. In addition, she conducted ethnography in London, interviewing and doing participant observation among qualified Portuguese emigrants in 2013, and later interviewing 20 Portuguese nurses in 12 countries by Skype. Pereira proposes that the recent mass emigration of nurses is a trend common to other peripheral countries in Europe, namely Spain, Italy and Romania. The majority of nurses from all these countries, and likewise the Portuguese, have moved to the UK. Secondly, Pereira argues that this happened mainly due to a macro "pull factor", when the UK put up obstacles to employing nurses from outside European countries - historically the Philippines and India - and recruiters had to search inside the European continent.

In Chap. 6, "Migrating to Complete Transitions. A Study of High-Skilled Youth Migration to France", Lopes argues that Portuguese youth emigrate as a way to complete the transition to adulthood. He focuses on skilled Portuguese emigrants who have moved to France, using extensive and intensive methodologies - namely a questionnaire survey and biographical interviews. Teixeira Lopes' main finding is that a strong push factor prompting young people to leave the country is the "blocked transition to adulthood". This means encountering impediments to finding a stable job in the country and the consequent difficulty of becoming economically independent, marrying and parenting. Emigrating to France allows these young people to fully become "adults".

In Chap. 7, "'Pulled' or 'Pushed'? The Emigration of Portuguese Scientists", Delicado's main finding from the analysis of outflows of Portuguese scientists is that Portugal is a semi-peripheral country according to the definitions of migrationsystems theory. The country both receives and sends scientists abroad, but many more researchers have left the country than have moved to Portugal. Delicado collected national statistics and has combined these with data from a questionnaire survey and in-depth interviews. Setting these migrations in the context of scientists' international mobility, she compares the role of pull and push factors in their decision to move, mainly to the USA and UK. Delicado ends by deepening the articulation between the macro perspective of national and international policies and the micro perspective of the scientists interviewed, critically analysing the advantages and disadvantages of the brain drain from peripheries to centres.

In Chap. 8, "Working Class Condition and Migrant Experience: The Case of Portuguese Construction Workers", Queirós lends visibility to a very significant social reality, but one that has remained practically invisible: the contemporary experience of Portuguese male construction workers abroad. The outputs are based on a multi-sited ethnography that took place during two different periods: the first between 2007 and 2008, when these workers moved from Portugal to Spain; and the second in 2014, when they re-emigrated to France after the financial crisis. These outflows to Spain and France reflect the global trend of Portuguese emigration in general, for which Spain became the top destination in the early 2000's and France one of the main five countries the Portuguese moved to after austerity policies were implemented in Portugal in 2011, as Pires shows in his chapter. Queirós' 
first conclusion is that the emigration of construction workers in both countries is temporary and circular; the author calls them the true "nomads" of today. Queirós' second conclusion is that the new work patterns and work-related mobilities ushered in by recent transformations in the civil construction sector - both at national and European level - apparently reinforce the subordinate integration of southern countries' economies and their workers in the larger European economy. This is due to existing social and economic inequalities between the sending and receiving countries inside the EU. He relates how the collective feeling of inferiority and the interiorization of social inequalities makes the moral and physical violence of everyday life in the workplace "normal", so it becomes naturalised. His final conclusion is that these work-related transformations - which lead to job instability and constant socio-geographic displacement - have a negative impact on workers' production rhythms as well as on their self-esteem.

In Chap. 9, Marques analyses the "Entrepreneurship among Portuguese nationals in Luxembourg". The majority of the small businesses owned by Portuguese emigrants are hotels and restaurants, followed by trade and construction companies. Entrepreneurship is particularly visible and important for labour integration in a country where the Portuguese are the largest immigrant population. The data is based on a survey carried out in 2012. Marques presents two main conclusions. First, transnational relations are weak because of the divergence between the time of demand and the time of supply of goods and services - and this is due to the type of business activity that predominates among these emigrants, i.e. mainly activity in the retail and hotel sectors. Secondly, these migrants' entrepreneurial activities have arisen from the identification of specific opportunities in the labour market, where they worked previously as employees, and the low level of bureaucratic difficulties they face.

The third section explores a distinguishing feature of Portuguese emigration: the "new" movements to "old" (former) colonies, namely Brazil and Angola.

In Chap. 10, "Contemporary Portuguese Migration Experiences in Brazil: Old Routes, New Trends", Rosales and Machado deepen our understanding of postcolonial settings through the perspective of Portuguese emigrants who have recently moved to São Paulo and Rio de Janeiro in Brazil. The data are drawn from a multisited ethnography of Portuguese emigrants from Lisbon and Porto living in these two cities, combined with questionnaires and statistical analysis. This old route, to Brazil, was the main path followed by the Portuguese for more than a century, from about 1850 until 1960. After 2011 the Portuguese once again started to emigrate to Brazil. While an old destination, there are now new trends in the social stratification of Portuguese emigrants who have moved to Brazil, as well as in their identities and strategies. Furthermore, their cultural practices are heterogeneous and differ between the two Brazilian cities. The authors conclude that in spite of new Portuguese emigrants having different tendencies to the "old" ones, colonial representations also structure their postcolonial perceptions of Brazil.

In Chap. 11, "Portuguese emigration to Angola (2000-2015): Strengthening a specific postcolonial relationship in a new global framework?", Candeias et al. present and discuss the contours and characteristics of recent Portuguese emigration to 
this African country (2000-2015). The chapter begins with a brief historical, demographic, social and political survey of Angola that also clarifies the migration nexus between Portugal and its former colony. The chapter's second part contextualises Portuguese emigration to Angola based on available statistics and on reviews of existing academic literature. The third section analyses the migration process and emigrant profiles. The study relies primarily on data gathered in a questionnaire survey involving a sample of 579 Portuguese citizens who migrated to Angola between 2000 and 2015. Particular attention is given to indicators concerning the dynamics of integration, the relations that the emigrants continue to uphold with Portugal and also the complex post-colonial nature of the process, which involves explicit and implicit links with the pre-independence period. Some of the chapter's main conclusions enable us to draw up a profile of Portuguese migrants in Angola: they are mostly male, over 35 years of age, and have a considerable level of academic and professional qualifications; also, most of them moved to Angola for professional reasons.

The fourth section of the book addresses the identities both of Portuguese emigrants in North America and of emigrants' descendants, the called "second generation".

In Chap. 12, “'II Was Enthused When I 'Returned' to Portugal, but I'm Leaving Disillusioned": Portuguese Migrant Descendant Returnees from Canada and Narratives of Return, Re-return and Twice Migration", Sardinha analyses the young Canadian descendants of Portuguese emigrants who decided to move to Portugal at the beginning of the twenty-first century. They are descendants of Portuguese migrants who went to Canada during the second wave of emigration. This was the period during which the highest number of Portuguese nationals moved to Canada: the early 1970's (cf. Vidigal 2018, 5). Afterwards, many emigrants decided to return to the country in the 1980s, 1990s and 2000s, as did their sons and daughters - the focus of this chapter. Sardinha's research draws on in-depth interviews carried out longitudinally from 2008 to 2015 . He explores their processes of integration and perceptions of Portuguese society. He finds that with the economic crisis the migrant descendants questioned their settlement, with some going back to Canada and others migrating to other countries. The descendants idealised a mythical notion of their parents' homeland nurtured by transnational activities related to Portugal in Canada, by holiday visits, and by the narrative of prosperity and modernity about the country that spread between the international events of Expo 1998 and the Euro 2004 football tournament, which made Portugal attractive to immigrants. On emigrating to Portugal they were confronted with everyday life in the country and further disillusionment with the bureaucracy and limitations in the job market. Sardinha concludes that these descendants decided to leave Portugal by making use of their transnational social capital and reactivating transnational networks.

In Chap. 13, "An Immigrant in America Yes, But Not an Emigrant in My Own Country! The Unbearable Weight of a Persistent Label", Cordeiro examines the interplay of simultaneously being a Portuguese "immigrant" in the USA and an "emigrant" from the USA in Portugal. As "two faces of the same coin", these two categories reveal symbolic relations of power. The author describes ongoing 
ethnographic fieldwork in Greater Boston, where she has researched the relations between identity, ethnicity and migration. In the case of the Portuguese-American in the USA, their status as "immigrants" in this huge "nation of immigrants" is perceived positively and used proudly; while in the homeland, Portugal, being an "emigrant" carries with it an historical (mis)representation of having left the country due to economic difficulties and low levels of formal education, and is thus generally a stigmatised category. The author concludes that perceptions of these two concepts, immigrant and emigrant, go beyond the dictionary definition used in migration statistics. The content of these categories differs according to migrants' nationalities and according to social and historical contexts.

The final reflections by King in Chap. 14, "New Migration Dynamics on the South-Western Periphery of Europe: Theoretical Reflections on the Portuguese Case", set "new" and "old" Portuguese emigration within a broader comparative framework. First, King contextualises the historical evolution and geographical destinations of Portuguese emigration within the comparative perspective of the "Southern European migration model". He details the model's four stages, showing how the countries from the southern periphery of Europe (Spain, Italy, Greece and Portugal) have structural aspects and processes in common. Secondly, King theorises Portuguese emigration, demonstrating how it fits into the core and (semi-) periphery systems. His main finding is that what distinguishes Portugal from the other Southern European peripheral countries is the "coexistence of Portugal's status as the metropolitan core of a (post)colonial periphery and its (semi)peripheral situation within Europe". King goes through the book's chapters, drawing links with existing studies of migration. He concludes by identifying what is missing from ongoing studies of Portuguese emigration, laying out a research agenda for future studies to address: the spatial origins of the emigrants in the country, return migration, the question of gender, and the relationship between emigration and economic and social development.

This edited volume draws attention to this new historical period of Portuguese emigration. Each of its chapter helps us reflect on the complex features of Portuguese emigration today, raising new questions that we hope may inform future debates.

Funding The proofreading of this chapter was funded by the Portuguese Emigration Observatory (Observatório da Emigração).

\section{References}

Åkesson, L. (2016). Moving beyond the colonial? New Portuguese migrants in Angola. Cahiers d'études Africaines, 1(221), 267-286.

Almeida, J. C. P. (2007). Citizens of the world: Migration and citizenship of the Portuguese in the UK. Portuguese Studies, 23(2), 208-299.

Baganha, M. I. (1994). As correntes emigratórias portuguesas no século XX e o seu impacto na economia nacional. Análise Social, XXIX(128), 959-980.

Baganha, M. I. (2003). Portuguese emigration after World War II. In A. C. Pinto (Ed.), Contemporary Portugal. Politics, society and culture (pp. 139-157). Boulder: Social Sciences Monographs. 
Baganha, M. I., \& Carlos Marques, J. (2001). População. In N. Valério (Ed.), Estatísticas históricas portuguesas (pp. 33-126). Lisbon: Instituto Nacional de Estatística.

Baganha, M. I., \& Góis, P. (1999). Migrações internacionais de e para Portugal: o que sabemos e para onde vamos. Revista Crítica de Ciências Sociais, 52/53. http://www.ces.uc.pt/myces/ UserFiles/livros/243_Baganha_G\%F3is 98\%3A99.pdf. Accessed 15 Sept 2017.

Bartolini, L., Gropas, R., \& Triandafyllidou, A. (2016). Drivers of highly skilled mobility from Southern Europe: Escaping the crisis and emancipating oneself. Journal of Ethnic and Migration Studies, 43(October), 1-22. https://doi.org/10.1080/1369183X.2016.1249048.

Beswick, J., \& Pozo-Gutiérrez, A. (2010). Migrant identities, sociolinguistic and socio-cultural practices: Spanish and Portuguese Migrations to the South Coast of England. Portuguese Studies, 26(1), 41-59. (J. Beswick \& M. Dinneen [Eds.], Portuguese-speaking Diaspora in Great Britain and Ireland: Special Issue).

Brutel, C. (2014). Les immigrés récemment arrivés en France. INSEE Première, 1524. http://www. insee.fr/fr/ffc/ipweb/ip1524/ip1524.pdf. Accessed 14 Sept 2014.

Bygnes, S. (2015). Are they leaving because of the crisis? The sociological significance of anomie as a motivation for migration. Sociology, 51(2), 258-273. https://doi. org/10.1177/0038038515589300.

Bygnes, S., \& Erdal, M. B. (2017). Liquid migration, grounded lives: Considerations about future mobility and settlement among Polish and Spanish Migrants in Norway. Journal of Ethnic and Migration Studies, 43(1), 102-118. https://doi.org/10.1080/1369183X.2016.1211004.

Canavarro, A., Areia, M., \& Pereira, M. (2014). Dossier temático: A nova vaga da emigração portuguesa. População e Sociedade, 22, 1-237.

Candeias, P., Góis, P., Marques, J. C., \& Peixoto, J. (2014). Emigração portuguesa: bibliografia comentada (1980-2013). 01/2014. SOCIUS Working Papers. Lisbon.

Candeias, P., Ferreira, B., \& Peixoto, J. (2014). Emigração portuguesa: o que temos vindo a estudar e o que nos falta saber - uma análise bibliométrica entre 1980 e 2013. População e Sociedade, 22, 11-34. http://www.cepesepublicacoes.pt/portal/pt/obras/populacao-e-sociedade-n-o-22. Acessed 15 Sept 2017.

Cândido, A. F. (2018). Portuguese skilled migration in DIOC 2010/11, OEm Fact Sheets, 8, Observatório da Emigração, CIES-IUL, ISCTE-IUL. https://doi.org/10.15847/ CIESOEMFS082018. http://observatorioemigracao.pt/np4/6119.html. Accessed 13 July 2018.

Carmo, R. M. d., \& Cantante, F. (2015). Desigualdades, redistribuição e o impacto do desemprego: tendências recentes e efeitos da crise económico-financeira. Sociologia, Problema e Práticas, 77, 33-51. https://doi.org/10.7458/SPP2015773311.

Carmo, R. M. d., Sebastião, J., Azevedo, J., Martins, S. d. C., \& Costa, A. F. d. (2018). Desigualdades Sociais: Portugal e a Europa. Mundos Sociais: Lisboa.

Castellani, S. (2018). Scivolando verso il basso. l'inserimento lavorativo dei nuovi migranti italiani e spagnoli in Germania durante la crisi economica. Sociologia Del Lavoro, 149(February), 77-93. https://doi.org/10.3280/SL2018-149006.

Christiane, H., \& Oliver, W. (2017). The role of argumentation and institutions for labour migration in the European Union - Exemplified by Spanish labour migration to Germany. International Migration, 55(S1), 69-85. https://doi.org/10.1111/imig.12338.

Cortés, A., Moncó, B., \& Betrisey, D. (2015). Movilidad Transnacional de Jóvenes Españoles y Latinoamericanos: una Comparación en Contextos de Crisis. Madrid: Centro Reina Sofía Sobre Adolescencia Y Juventud.

Domínguez-Mujica, J., \& Gracía, T. P. (2017). The economic crisis and the Southern European migration model. In B. Glorius \& J. Domínguez-Mujica (Eds.), European mobility in times of crisis: The new context of European South-North Migration (pp. 17-48). Bielefeld: Transcript.

Espírito-Santo, I., \& Pires, R. P. (2014). Estados Unidos da América, OEm Country Reports, 2, Lisboa, Observatório da Emigração, CIES-IUL, ISCTE-IUL. https://doi.org/10.15847/ CIESOEMCR022014.

Estanque, E. (2016). Onde pára a classe média? Breves notas sobre o conceito e a realidade portuguesa. Sociologia, Problemas e Práticas, 2017(83), 37-54. https://doi.org/10.7458/ SPP2017839971. 
Faraco, B. C. (2014). Neue migration. Junge Spanier/Innen in Berlin. In C. Pfeffer-Hoffmann (Ed.), Arbeitsmigration aus Spanien vor dem Hintergrund der Migrationsprozesse seit 1960 (pp. 214-234). Berlin: Mensch \& Buch.

Farcas, D., \& Gonçalves, M. (2017). Motivations and cross-cultural adaptation of self-initiated expatriates, assigned expatriates, and immigrant workers: The case of Portuguese migrant workers in the United Kingdom. Journal of Cross-Cultural Psychology, 48(7), 1028-1051. https://doi.org/10.1177/0022022117717031.

Ferreira, S. (2016). A emigração portuguesa e os seus meios de comunicação social: breve caracterização (OEm Working-Paper, 2). Lisboa: Observatório da Emigração, CIES-IUL, ISCTE-IUL. https://doi.org/10.15847/CIESOEMWP022016. http://observatorioemigracao.pt/ np4/5097.html. Accessed 19 Sept 2017.

Ganga, R., Silva, J. P., Gomes, R., Vaz, H., Lopes, J. T., Silva, S., Cerdeira, L., et al. (2016). Portuguese scientists' migration: A study on the 2008 crisis aftermath. International Migration, 54(6), 43-55. https://doi.org/10.1111/imig.12271.

Gibson, H. D., Palivos, T., \& Tavlas, G. S. (2014). The crisis in the euro area: An analytic overview. Journal of Macroeconomics, 39, 233-239. https://doi.org/10.1016/j.jmacro.2013.09.014.

Glynn, I., Kelly, T., \& MacÉinrí, P. (2013). Irish emigration in an age of austerity. Cork: University College Cork.

Góis, P., \& Marques, J. C. (2009). Portugal as a semi-peripheral country in the global migration system. International Migration, 47(3), 21-50. https://doi.org/10.1111/j.1468-2435.2009.00523.x.

Gomes, R. M., Lopes, J. T., Vaz, H., Cerdeira, L., Ganga, R., de Lourdes, M. M., Magalhães, D., et al. (2015). Fuga de cérebros: retratos da emigração portuguesa qualificada. Lisboa: Bertrand.

González-Ferrer, A. (2013). La nueva emigración española. Lo que sabemos y lo que no. Fundación Alternativas. http://digital.csic.es/handle/10261/93167. Accessed 8 Mar 2018.

Herm, A., \& Poulain, M. (2012). Economic crisis and international migration. What the EU data reveal? Revue Européenne des Migrations Internationales, 28(4), 145-169. https://doi. org/10.4000/remi.6171.

Herrera, M. J. (2014). Migración cualificada de trabajadores de España al extranjero. In J. Arango, D. M. Malapeira, \& J. O. Alonso (Eds.), Inmigración y emigración: mitos y realidades. Anuario de la Inmigración en España (Vol. 2013, pp. 99-109). Barcelona: CIDOB (Barcelona Centre For International Affaris).

Jornal de Negócios. (2013, January 17). As várias declarações de apelo à emigração. Jornal de Negócios. http://www.jornaldenegocios.pt/economia/detalhe/as_varias_declaracoes_de_ apelo_a_emigracao.html. Accessed 7 Apr 2014.

Justino, D. (2016). Emigration from Portugal: Old wine in new bottles? Washington, DC: Migration Policy Institute.

King, R. (2000). Southern Europe in the changing global map of migration. In R. King, G. Lazaridis, \& C. Tsardanidis (Eds.), Eldorado or fortress? Migration in Southern Europe (pp. 1-26). London: Macmillan.

King, R. (2015). Migration and Southern Europe - A center-periphery dynamic? In M. Baumeister \& R. Sala (Eds.), Southern Europe? Italy, Spain, Portugal and Greece from the 1950s to the present day (pp. 139-169). Frankfurt/New York: Campus.

King, R., Lulle, A., Conti, F., \& Mueller, D. (2016). Eurocity London: A qualitative comparison of graduate migration from Germany, Italy and Latvia. Comparative Migration Studies, 4(3), 1-22. https://doi.org/10.1186/s40878-016-0023-1.

Lafleur, J.-M., \& Stanek, M. (2016). Lessons from the South-North migration of EU Citizens in times of crisis. In J.-M. Lafleur \& M. Stanek (Eds.), South-North migration of EU citizens in times of crisis (IMISCOE Research Series) (pp. 215-224). Dordrecht: Springer. https://doi. org/10.1007/978-3-319-39763-4.

Leal, J. (2017). O Culto do Divino. Migrações e Transformações. Lisboa: Edições 70.

Leite, A. C., Cardoso, S. G., Marques, A. G., \& Morais, C. (2017). Believing is adapting': Belief in a just world and emigrants' identification and satisfaction with the host country. Revista de Psicología Social, 32(2), 424-439. https://doi.org/10.1080/02134748.2017.1291743.

Lopes, J. T. (2014). Geração Europa. Um estudo sobre a jovem emigracão qualificada para França. Lisboa: Mundos Sociais. 
Mamede, R. P. (2016). A crise existencial do euro. In E. P. Ferreira (Ed.), União Europeia. Reforma ou declínio. Lisboa: Vega.

Marques, J. C., \& Góis, P. (2013). Portuguese emigrants and the state: An ambivalent relationship. In M. Collyer (Ed.), Emigration nations policies and ideologies of emigrant engagement (pp. 252-276). Basingstoke: Palgrave Macmillan.

Observatório da Emigração. (2015). Portuguese emigration factbook 2015. Lisbon: Observatório da Emigração, CIES-IUL, ISCTE-IUL. https://doi.org/10.15847/CIESOEMFB2015. http:// observatorioemigracao.pt/np4EN/4924.html. Accessed 9 Nov 2017.

Observatório da Emigração. (2017a). Data/Global estimates. Data. http://observatorioemigracao. $\mathrm{pt} / \mathrm{np} 4 \mathrm{EN} / \mathrm{Dados} /$

Observatório da Emigração. (2017b). Portuguese emigration factbook 2016. Lisbon: Observatório da Emigração, CIES-IUL, ISCTE-IUL. https://doi.org/10.15847/CIESOEMFB2016. http:// observatorioemigracao.pt/np4EN/5810.html. Accessed 9 Dec 2017.

Observatório da Emigração. (2018). Portuguese emigration factbook 2017. Lisbon: Observatório da Emigração, CIES-IUL, ISCTE-IUL. https://doi.org/10.15847/CIESOEMFB2017. http:// observatorioemigracao.pt/np4EN/5999.html. Accessed 9 Mar 2018.

OECD. (2011). International migration outlook. SOPEMI 2011. Paris: OECD Publications.

Oliveira, I. T. d., Candeias, P., Peixoto, J., Azevedo, J., \& Malheiros, J. M. (2016). Regresso e circulação de emigrantes portugueses no início do século XXI. Sociologia, Problemas e Práticas, 2016(81), 11-35. https://doi.org/10.7458/SPP2016817155.

Parutis, V. (2014). 'Economic migrants' or 'middling transnationals'? East European migrants' experiences of work in the UK. International Migration, 52(1), 36-55. https://doi. org/10.1111/j.1468-2435.2010.00677.x.

Pedroso, P. (2014). Portugal and the global crisis - The impact of austerity on the economy, the social model and the performance of the state. Berlin: Friedrich-Ebert-Stiftung. http://library. fes.de/pdf-files/id/10722.pdf. Accessed 9 May 2016.

Peixoto, J. (2000). A emigração. In F. Bethencourt \& K. Chaudhuri (Eds.), História da expansão portuguesa (pp. 152-181). Lisboa: Círculo de Leitores.

Peixoto, J. (2012). A emigração portuguesa hoje: o que sabemos e o que não sabemos. In SOCIUS Working Papers (pp. 5-2012). Lisboa: Instituto Superior de Economia e Gestão (ISEG).

Peixoto, J., Oliveira, I. T. D., Azevedo, J., Marques, J. C., Góis, P., Malheiros, J., \& Madeira, P. (2016). Regresso ao futuro - A nova emigração ea sociedade portuguesa. Lisboa: Gradiva.

Pereira, C. (2015). Vidas partidas. Enfermeiros portugueses no estrangeiro. Loures: Lusodidacta.

Pereira, C., Pinto, N., \& Pires, R. (2015). Portuguese nurses in the UK 2014/Enfermeiros portugueses no Reino Unido 2014. OEm Fact Sheets, 3, Observatório da Emigração. CIES-IUL, ISCTE-IUL. https://doi.org/10.15847/CIESOEMFS032015-pt-en. http://observatorioemigracao.pt/np4EN/4317.html. Accessed 19 Sept 2016.

Pinho, F., \& Pires, R. P. P. (2013). Espanha, OEm Country Reports, 1. Lisbon, Observatório da Emigração, CIES-IUL, ISCTE-IUL. https://doi.org/10.15847/CIESOEMCR012013. http:// www.observatorioemigracao.pt/np4/3725.html. Accessed 7 Aug 2014.

Pires, R. P., \& Espírito-Santo, I. (2016). Saldos migratórios 2000-2013. OEm Fact Sheets, 4,1-19. Observatório da Emigração, CIES-IUL, ISCTE-IUL. https://doi.org/10.15847/ CIESOEMFS042016. http://observatorioemigracao.pt/np4/5603.html. Accessed 1 Mar, 2017.

Pires, R. P. (Ed.), Machado, F. L., Peixoto, J., Vaz, M. J. V., with Pinho, F., Azevedo, J., Sabino, C., \& Chalante, S. (2011). Portugal: An atlas of international migration. Lisboa: Tinta da China.

Pires, R. P., Pereira, C., Azevedo, J., Espírito-Santo, I., Vidigal, I., \& Ribeiro, A. C. (2015). Emigração portuguesa. Relatório estatístico 2015. Lisboa: Observatório da Emigração e Rede Migra, CIES-IUL, ISCTE-IUL, e DGACCP. https://doi.org/10.15847/CIESOEMRE022015.

Pires, R. P., Pereira, C., Azevedo, J., Vidigal, I., \& Veiga, C. M. (2017). Emigração portuguesa. Relatório estatístico 2017. Lisboa: Observatório da Emigração e Rede Migra, CIESIULISCTE-IUL, e DGACCP. https://doi.org/10.15847/CIESOEMRE042017.

PORDATA-INE. (2017). População desempregada: total e por grupo etário. Emprego e mercado de trabalho. https://www.pordata.pt/Portugal/População+desempregada+total+e+por+grupo+e tário-40. Accessed 25 May 2017. 
Raffini, L. (2014). Quando la Generazione Erasmus incontra la Generazione Precaria. La mobilità transnazionale dei giovani italiani e spagnoli. OBETS. Revista de Ciencias Sociales, 9, 139165. https://doi.org/10.14198/OBETS2014.9.1.05.

Reichlin, L. (2014). Monetary policy and banks in the euro area: The tale of two crises. Journal of Macroeconomics, 39, 387-400. https://doi.org/10.1016/j.jmacro.2013.09.012.

REMIGR. (2017). Inquérito aos Portugueses no Estrangeiro, 2014-15, base de dados [Survey to Portuguese Abroad, 2014-15, database]. Observatório da Emigração. http://observatorioemigracao.pt/np4EN/524. Accessed 25 June 2017.

Rocha-Trindade, M. B. (1976). Comunidades migrantes em situação dipolar: análise de três casos de emigração especializada para os EUA, para o Brasil e para França. Análise Social, XII(48), 983-997.

Rocha-Trindade, M. B., \& Arroteia, J. (1984). Bibliografia da emigração portuguesa. Lisboa: Instituto de Português de Ensino à Distância.

Ros, C. R. (2013). Londres minusculastierra prometida. La emigración de jóvenes titulados universitarios catalanes a Londres. Perifèria. Revista de Recerca I Formació En Antropologia, $18(2), 158-174$.

Santana-Pereira, J., \& Horta, A. P. H. (2017). A global nation? The evolution of emigration and diaspora policies in Portugal (1960-2016). In A. Weinar (Ed.), Emigration and diaspora policies in the age of mobility (Vol. 9, pp. 121-137). Cham: Springer International Publishing. https://doi.org/10.1007/978-3-319-56342-8.

Santos, I. d. (2013). L'émigration au Portugal, avatar d'un pays 'semi-périphérique', métropole postcoloniale. Hommes et Migrations, 1302, 157-161.

Teixeira, A. A. C., Silva, E., \& Mamede, R. P. (Eds.). (2014). Structural change, competitiveness and industrial policy: Painful lessons from the European periphery. Routledge: Taylor \& Francis Group.

Triandafyllidou, A., \& Gropas, R. (2014). 'Voting with their feet': Highly skilled emigrants from Southern Europe. American Behavioral Scientist, May, 1-20. https://doi. org/10.1177/0002764214534665.

Triandafyllidou, A., \& Isaakyan, I. (Eds.). (2016). High-skill migration and recession. Gendered perspectives. London: Palgrave Macmillan UK. https://doi.org/10.1057/9781137467119.

United Nations. (1998). Recommendations on statistics of international migration-Rev 1. Statistical Papers Series M (58). http://unstats.un.org/unsd/publication/SeriesM/SeriesM_58rev1E.pdf. Accessed 12 Dec 2012.

Vidigal, I. (2018). Emigração portuguesa para o Canadá, 1966-2016, OEm Fact Sheets, 7, Observatório da Emigração, CIES-IUL, ISCTE-IUL. https://doi.org/10.15847/ CIESOEMFS072018. http://observatorioemigracao.pt/np4/6133.html. Accessed 1 June 2018.

Open Access This chapter is licensed under the terms of the Creative Commons Attribution 4.0 International License (http://creativecommons.org/licenses/by/4.0/), which permits use, sharing, adaptation, distribution and reproduction in any medium or format, as long as you give appropriate credit to the original author(s) and the source, provide a link to the Creative Commons licence and indicate if changes were made.

The images or other third party material in this chapter are included in the chapter's Creative Commons licence, unless indicated otherwise in a credit line to the material. If material is not included in the chapter's Creative Commons licence and your intended use is not permitted by statutory regulation or exceeds the permitted use, you will need to obtain permission directly from the copyright holder.

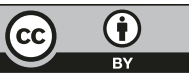

